\title{
How learning to read and write influences the dialectal traits in -sC clusters
}

Isabel Henriques

Clup-Centro de Linguística da Universidade do Porto, Portugal

https://doi.org/10.36505/ExLing-2010/03/0016/000136

\begin{abstract}
Words written with the initial graphic sequences "es+C" and "ex+C" raise many problematic questions to the phonology of European Portuguese since the production of these sequences is changing (Delgado Martins et al, 1996:302). This paper focuses on the analysis of how the speakers produce and segment these $-s C$ clusters and on the variables that might affect these tasks. Therefore, we conducted a study to perceive what might influence the speakers' phonological knowledge.
\end{abstract}

Key words: phonological knowledge, orthographic knowledge, dialectal traits, variation and change

\section{Introduction}

Words with the initial $-s C$ clusters are definitely a controversial topic in the phonology of European Portuguese, as in other Romance languages, especially when the syllabic status of the cluster has to be defined since the production of these sequences is being modified (Delgado Martins et al. 1996:302) by the loss of the initial vowel. The difficulty arises when the speakers have to identify the syllabic constituents, since the word initial $-s C$ clusters cannot be accepted as tautosyllabic (Veloso 2002), because they violate the Sonority Principle (Selkirk 1982:343; 1984:110).

The problem only arises in initial clusters of words with the graphic sequences "es+C" and "ex+C", as the initial vowel tends to disappear and they are also produced differently due to the dialectal origin of the speakers, especially among speakers from the septentrional (Northern area-Oporto) and central meridional dialect (Southern areaLisbon). There is a clearer tendency to vowel deletion in the central meridional dialect, while in the septentrional dialect vowel insertion is more frequent, according to the dictionaries and the characteristics of the two dialects (Barros Ferreira et al. 1996: 495, based on Cintra 1970).

Some of the core concerns in the study of these sequences, as well of this paper, are:

i) If these sequences are considered tautosyllabic, we are facing a violation of the Sonority Principle (Selkirk 1984:110) and of the Dissimilarity Condition.

ExLing 2010: Proceedings of 3rd Tutorial and Research Workshop on Experimental Linguistics, 25-27 August, Athens, Greece 
ii) It may be a difficult task for speakers to clearly define the syllable boundaries.

iii) There may be some variation due to the dialectal origin of the speakers.

iv) There may be some influence of the orthographic knowledge in the way the speakers produce and segment these words, since there is an initial graphic vowel, <e>.

v) The orthographic knowledge may be changing the dialectal traits.

\section{Experimental study}

Elaborating on the analyses available in the literature for European Portuguese (Freitas 1997, 2000; Andrade and Rodrigues 1999; Rodrigues 2000; Rodrigues 2003; Freitas and Rodrigues 2003), we considered to be fundamental to conduct an experimental study which was orientated with following aims:

i) to find evidence that the orthographic knowledge interferes with the phonological knowledge (Veloso 2003) and with the changing trend in the production of these sequences;

ii) to determine if we can talk about variation in case the sequence fricative plus plosive may be considered tautosyllabic by the speakers;

iii) to test the influence of the dialect in the two orthographic sequences ("es+C" and "ex+C").

Having these purposes in mind, we selected some speakers from different age groups and from different dialectal origin. We chose 10 speakers who attended the $5_{\text {th }}$ grade and the $9_{\text {th }}$ grade from Lisbon (central meridional dialect) and Oporto (septentrional dialect). The speakers were asked to produce the words with $-s C$ clusters (e.g. espada/sword; escola/school; exposiçãolexhibition; experiêncial experience) and segment the syllables of those words, after some images were shown.

All the interviews were recorded; then, the recordings were carefully heard several times and finally the data were analysed with SPSS16, in order to see what were the statistically significant differences. We have chosen the Mann-Whitney test because we were testing two independent variables: the orthographic knowledge and the dialect.

\section{Results}

The results of the production of the $-s C$ clusters without initial vowel were not statistically significant among the speakers of the 5 th grade from the two dialects $(\mathrm{z}=-0,506$; n.s.). While the results of the production without initial vowel of the $-s C$ clusters among the speakers of the $9_{\text {th }}$ grade of the two 
dialectal groups were statistically significant $(\mathrm{z}=-2,834 ; \mathrm{p}<0,005)$. The results of the task of segmentation were not statistically significant in both groups, regardless of the dialectal origin.

\section{Conclusions}

Some of the data showed that the dialectal traits may be disappearing due to the influence of learning to read and write. Therefore, one must conclude that some of the dialectal traits may be changing, when the speakers produce and segment these sequences. While there was a clear tendency to vowel deletion in the production (e.g. [Jkole]-escola/school), the segmentation led to vowel insertion (e.g. [if-kole]). Nonetheless, some dialectal traits still persist, such as: the speakers from Oporto attending the ninth grade showed a clear tendency to the insertion of vowels ([i],[i] and diphthongs [ej], [ej]) both in the production and segmentation of these clusters.

After the experimental study we can conclude that:

i) The speakers from the Northern dialect tend to produce these sequences with an initial vowel but there is no statistically significant difference, with the exception of the speakers attending the $9^{\text {th }}$ grade.

ii) Words with initial $-s C$ clusters are segmented as heterosyllabic.

iii) Speakers introduce a vowel in the segmentation.

iv) The results were similar among the different groups regardless of the school year or dialect. So, the dialect differences are fading as a consequence of the process of learning to read and write.

v) There was a certain influence of the orthographic knowledge, especially in the words with the graphic sequence "ex $+\mathrm{C}$ ".

On the other hand, some of the early predictions proved to be wrong or at least inconclusive, such as:

i) The possibility of tautosyllabic segmentation, based on Delgado-Martins (1996:302). This hypothesis did not occur in this study.

ii) The possibility of change and variation. The only change is the fact that the results of both dialectal groups are similar, which was unexpected since there are some clear differences in the production of these sequences. This is possibly the result of orthographic knowledge.

To sum up, the similar results among the different groups from different dialects may be due to the influence of the orthographic knowledge acquired at school.

Nonetheless, there are still questions related to the 'grey area' of the position of the fricative [J] in the syllable. These can be some of the topics to 
be considered in a future study with more data from language acquisition, tests with larger number of speakers and also with different tasks, such as reading and spontaneous speech.

\section{References}

Barros Ferreira, M. et al. 1996. Variação Linguística: perspectiva dialectológica. In Introdução à Fonologia Geral e Portuguesa. Lisboa. Caminho, 479-502.

D’Andrade, E., Rodrigues, C. 1999. Das Escolas e das Culturas: História de uma sequência consonântica. Actas do XIV Encontro Nacional da Associação Portuguesa de Linguística. Lisboa: APL/Colibri, 117- 133.

Delgado-Martins, R. et al.. 1996. Fenómenos de Reestruturação Silábica em Português de Lisboa. In: M. R. Delgado-Martins. 2002. Fonética do Português. Trinta anos de Investigação. Lisboa, Caminho, 301-318.

Freitas, M.J. 1997. Aquisição da Estrutura Silábica do Português Europeu. Dissertação de Doutoramento. Universidade de Lisboa.

Freitas, M.J. 2000. O grupo consonântico s+C em início de palavra na aquisição do português europeu. Actas do XV Encontro Nacional da Associação Portuguesa de Linguística. Lisboa: APL/Colibri, 499-512.

Freitas, M.J., Rodrigues, C. 2003. O grupo consonântico s+C em início de palavra na aquisição do português europeu. Actas do XV Encontro Nacional da Associação Portuguesa de Linguística. Lisboa: APL/Colibri, 499-512.

Rodrigues, C. 2000. Novos Dados acerca de /\# S\$C/. Actas do XV Encontro Nacional da Associação Portuguesa de Linguística. Lisboa: APL/Colibri, II, 287299.

Selkirk, E.. 1982. The Syllable. In Van der Hulst, H., Smith, Norval. The Structural of Phonological Representations. Part II. Dordrecht, Foris Publications. 337-361.

Selkirk, E.. 1984. On the Major Class Features and Syllable Theory. In Aronoff, M. Language, Sound and Structure. Studies Presented to Morris Halle by his teacher and student, 107-136.

Veloso, J. 2002. Do Fricative+ Plosive Onsets exist word-initially in European Portuguese?. In: A. Eftimova, K. Petrova (Eds.). Litora Psycholinguistica. Sofia: Sema RSH, 49- 56.

Veloso, J. 2003. Da Influência do Conhecimento Ortográfico sobre o Conhecimento Fonológico. Dissertação de Doutoramento apresentada à Faculdade de Letras da Universidade do Porto. 